\title{
A review of the synthesis and characterization of anion exchange membranes
}

\author{
Kimberly F. L. Hagesteijn ${ }^{1}$ (1), Shanxue Jiang ${ }^{1}$ (D), and Bradley P. Ladewig ${ }^{1, \star}$ (]) \\ ${ }^{1}$ Barrer Centre, Department of Chemical Engineering, Imperial College London, London, UK
}

Received: 21 March 2018

Accepted: 5 May 2018

Published online:

21 May 2018

(C) The Author(s) 2018

\begin{abstract}
This review highlights advancements made in anion exchange membrane (AEM) head groups, polymer structures and membrane synthesis methods. Limitations of current analytical techniques for characterizing AEMs are also discussed. AEM research is primarily driven by the need to develop suitable AEMs for the high-pH and high-temperature environments in anion exchange membrane fuel cells and anion exchange membrane water electrolysis applications. AEM head groups can be broadly classified as nitrogen based (e.g. quaternary ammonium), nitrogen free (e.g. phosphonium) and metal cations (e.g. ruthenium). Metal cation head groups show great promise for AEM due to their high stability and high valency. Through "rational polymer architecture", it is possible to synthesize AEMs with ion channels and improved chemical stability. Heterogeneous membranes using porous supports or inorganic nanoparticles show great promise due to the ability to tune membrane characteristics based on the ratio of polymer to porou2s support or nanoparticles. Future research should investigate consolidating advancements in AEM head groups with an optimized polymer structure in heterogeneous membranes to bring together the valuable characteristics gained from using head groups with improved chemical stability, with the benefits of a polymer structure with ion channels and improved membrane properties from using a porous support or nanoparticles.
\end{abstract}

Abbreviations

AAEM Alkaline anion exchange membrane

AEM Anion exchange membrane

AEMFC Anion exchange membrane fuel cell

AEMWE Anion exchange membrane water electrolysis
CEM Cation exchange membrane

DSC Differential scanning calorimetry

IEC Ion exchange capacity ( $\mathrm{mmol} / \mathrm{g})$

IEM Ion exchange membrane

PEMFC Proton exchange membrane fuel cell

Address correspondence to E-mail: b.ladewig@imperial.ac.uk 


$\begin{array}{ll}\text { PEMWE } & \begin{array}{l}\text { Proton exchange membrane water } \\ \text { electrolysis }\end{array} \\ \text { QA } & \text { Quaternary ammonium } \\ \text { SR } & \text { Swelling ratio (\%) } \\ \text { TGA } & \text { Thermogravimetric analysis } \\ \text { WU } & \text { Water uptake }(\%)\end{array}$

\section{List of symbols}

\begin{tabular}{|c|c|}
\hline$A$ & $\begin{array}{l}\text { Membrane cross-sectional area } \\
\text { (width } \times \text { thickness })\left(\mathrm{cm}^{2}\right)\end{array}$ \\
\hline$C_{\text {acid }}$ & Acid concentration $(\mathrm{mmol} / \mathrm{ml})$ \\
\hline $\mathrm{C}_{\mathrm{AgNO}_{3}}$ & $\mathrm{AgNO}_{3}$ concentration $(\mathrm{mmol} / \mathrm{ml})$ \\
\hline$C_{\text {base }}$ & Base concentration $(\mathrm{mmol} / \mathrm{ml})$ \\
\hline$\gamma$ & $\begin{array}{l}\text { Water content }\left(\mathrm{H}_{2} \mathrm{O} \text { molecules } / \text { mobile }\right. \\
\text { anion) }\end{array}$ \\
\hline$L$ & Length between inner electrodes $(\mathrm{cm})$ \\
\hline$l_{\mathrm{w}}$ & Membrane wet length $(\mathrm{cm})$ \\
\hline$l_{\mathrm{d}}$ & Membrane dry length $(\mathrm{cm})$ \\
\hline$m_{\mathrm{d}}$ & Membrane dry mass (g) \\
\hline$m_{\mathrm{w}}$ & Membrane wet mass $(\mathrm{g})$ \\
\hline $\mathrm{MW}_{\mathrm{H}_{2} \mathrm{O}}$ & Molecular weight of water $(\mathrm{g} / \mathrm{mol})$ \\
\hline$R_{\mathrm{m}}$ & Membrane resistance $(\Omega)$ \\
\hline$\sigma$ & Conductivity $(\mathrm{S} / \mathrm{cm})$ \\
\hline$V_{\text {acid }}$ & Acid volume added (ml) \\
\hline$V_{\text {base }}$ & Base volume added (ml) \\
\hline$V_{\mathrm{AgNO}_{3}}$ & $\mathrm{AgNO}_{3}$ volume added $(\mathrm{ml})$ \\
\hline
\end{tabular}

\section{Introduction}

Ion exchange membranes (IEM) are semi-permeable membranes composed of ionic head groups attached to polymer matrices [1]. They can be broadly classified as anion exchange membranes (AEM) and cation exchange membranes (CEM) depending on the type of ion that is permitted to cross the membrane layer $[2,3]$. For example, AEMs contain positively charge head groups in the membrane which permit the passage of anions while repelling cations [3]. AEMs can be further refined based on the types of anions they pass, with AEMs passing non-alkaline form anions (e.g. $\mathrm{Cl}^{-}, \mathrm{SO}_{4}{ }^{2-}, \mathrm{PO}_{4}{ }^{3-}$ ) and alkaline anion exchange membranes (AAEMs) passing alkaline form anions (e.g. $\mathrm{OH}^{-}, \mathrm{HCO}_{3}{ }^{-}, \mathrm{CO}_{3}{ }^{2-}$ ) [2].

By exploiting the selective nature of IEMs, a variety of applications exist for both AEMs and CEMs. Commercialized IEM applications are primarily found in water/wastewater treatment applications such as desalination or high-purity water production in food \& beverage, pharmaceutical, semiconductor and power generation applications [e.g. electrodialysis (ED), electrodialysis reversal (EDR), electrodeionization (EDI) and bipolar membrane electrodialysis (BMED)] [4-6]. Commercialized IEM applications are also found in inorganic acid/base production (e.g. BMED) and acid/base recovery [e.g. diffusion dialysis (DD)] [5]. Other water treatment processes under development include Donnan dialysis to remove harmful pollutants and scaling species from water/wastewater streams [7-9] and ion exchange membrane bioreactor to combine the benefits of IEMs with biological treatment for groundwater remediation and water/wastewater treatment [10-12]. Driven by the need for sustainable energy generation and storage, innovative applications under development include fuel cells, water electrolysis, reverse electrodialysis and redox flow batteries [5, 13-15].

Specific to AEMs, research is focused on developing AAEMs for high-pH and high-temperature applications such as anion exchange membrane fuel cells (AEMFC) and anion exchange membrane water electrolysis (AEMWE) [13, 16, 17]. The principle behind fuel cells is to convert energy stored in chemical bonds to generate electricity and produce water as waste [18]. On the other hand, water electrolysis uses DC electricity to split water and generate hydrogen and oxygen gas [19]. Together, these two technologies, in conjunction with other renewable energy sources (e.g. solar, wind), are viewed as a potential solution to develop a "hydrogen economy" that utilizes renewable energy in place of fossil fuels and does not produce $\mathrm{CO}_{2}[20,21]$.

Researchers are motivated to advance AEMFC/ AEMWE technologies to be in line with complementary technologies that use CEMs: cation exchange membrane fuel cells (or proton exchange membrane fuel cells, PEMFC) and proton exchange membrane (or polymer electrolyte membrane) water electrolysis, PEMWE) [13, 16, 22]. Figure 1 presents a schematic of a typical AEMFC, PEMFC, AEMWE and PEMWE. In a fuel cell, fuels, usually hydrogen gas or low molecular weight alcohols (e.g. methanol, ethanol, ethylene glycol), are fed into the fuel cell where it contacts a catalytic layer that facilitates a chemical reaction to generate electrons $[18,23]$. Depending on the type of IEM, either $\mathrm{H}^{+}$or $\mathrm{OH}^{-}$ions are transported across the membrane where a second catalytic layer facilitates a chemical reaction to produce water. In conjunction with these chemical reactions, 
(a)

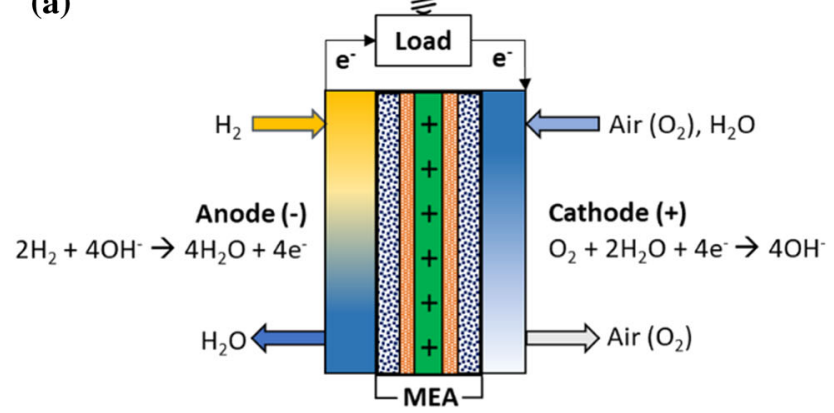

Overall: $2 \mathrm{H}_{2}+\mathrm{O}_{2} \rightarrow 2 \mathrm{H}_{2} \mathrm{O}+4 \mathrm{e}^{-}$

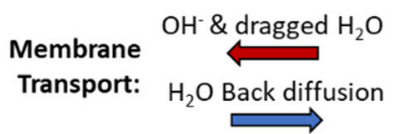

(c)

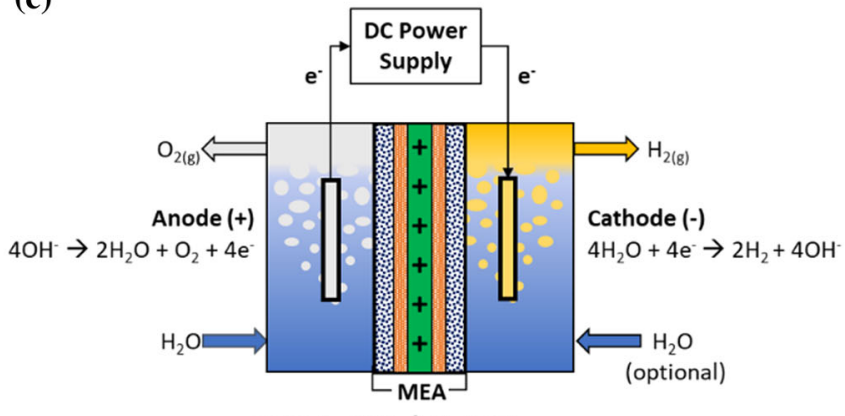

Overall: $2 \mathrm{H}_{2} \mathrm{O} \rightarrow \mathrm{O}_{2}+2 \mathrm{H}_{2}$

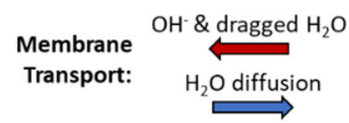

(e)

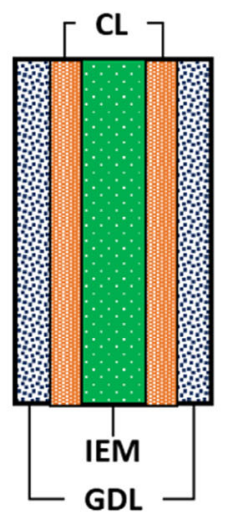

(b)

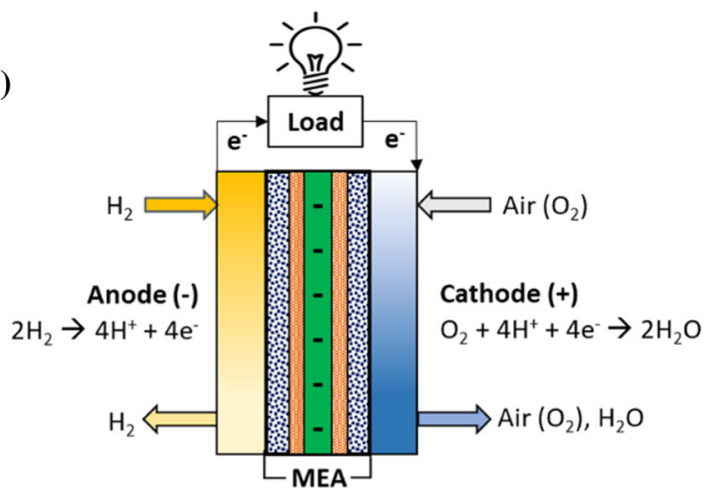

Overall: $2 \mathrm{H}_{2}+\mathrm{O}_{2} \rightarrow 2 \mathrm{H}_{2} \mathrm{O}+4 \mathrm{e}^{-}$

Membrane $\mathrm{H}^{+} \&$ dragged $\mathrm{H}_{2} \mathrm{O}$

Transport:

(d)

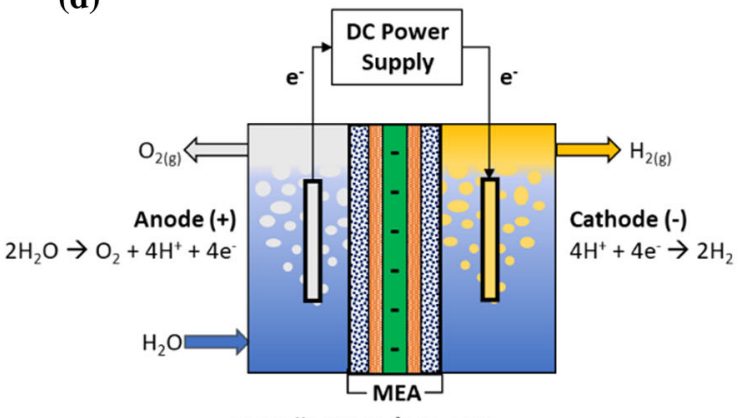

Overall: $2 \mathrm{H}_{2} \mathrm{O} \rightarrow \mathrm{O}_{2}+2 \mathrm{H}_{2}$

Membrane $\mathrm{H}^{+}$\& dragged $\mathrm{H}_{2} \mathrm{O}$

Transport:

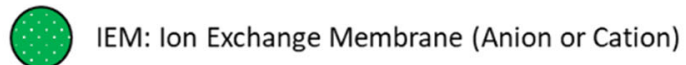

CL: Catalyst Layer

GDL: Gas Diffusion Layer

Figure 1 Schematic of anion exchange membrane fuel cell (a), proton exchange membrane fuel cell (b), anion exchange membrane water electrolysis (c), proton exchange membrane water electrolysis (d) and membrane electrode assembly (e). 
electrodes are connected on either side of the IEM to complete the electrical circuit and allow electrons to travel from anode to cathode, which generates an electric current [24, 25]. In water electrolysis, a DC current is applied across two electrodes and splits water into near pure hydrogen gas (cathode) and oxygen gas (anode) streams [19]. A membrane or diaphragm is used to prevent the hydrogen and oxygen gas streams from mixing, which reduces the electrolyser efficiency [26]. It is also permeable to $\mathrm{H}^{+}$, $\mathrm{OH}^{-}$and $\mathrm{H}_{2} \mathrm{O}$ to keep charges in balance between anode and cathode [21].

Historically, PEMFC/PEMWE have seen greater advancements compared to AEMFC/AEMWE primarily due to the ability to create CEMs with high $\mathrm{H}^{+}$ conductivities. For example, Nafion ${ }^{\circledR} 117$ membrane by DuPont, one of the most commonly used CEMs, has a reported $\mathrm{H}^{+}$conductivity of $78 \mathrm{mS} / \mathrm{cm}$ [27], whereas most anion conductivities in AAEMs have been reported between 5 and $20 \mathrm{mS} / \mathrm{cm}$ [25, 28]. Within the past 5 years, AAEM conductivities have widely been reported from 50 to $100 \mathrm{mS} / \mathrm{cm}$, with some even as high as $200 \mathrm{mS} / \mathrm{cm}[29,30]$. This is in part due to (a) a focus on optimizing AEM chemistry, (b) advancements in understanding the relationship between conductivity and water uptake and (c) improved conductivity measurement techniques $[16,29,31,32]$. Given that higher AAEM conductivities have been correlated with increased water update, up to a plateau around $100 \mathrm{mS} / \mathrm{cm}$ at which point the water update dilutes the ionic charge and reduces conductivity, by ensuring sufficient hydration at the cathode of a fuel cell, improved conductivities can be achieved [29]. Furthermore, the detrimental effect of carbonate and bicarbonate formation on true $\mathrm{OH}^{-}$conductivities has been shown to be significant with true $\mathrm{OH}^{-}$conductivity values measured via $\mathrm{CO}_{2}$-free environment being double the conductivity values measured via current procedures in ambient air environments [31]. Additionally, CEMs have better chemical stability and higher solubility in low boiling point solvents compared to AAEMs, which lead to easier and "greener" CEM synthesis [24]. As discussed in this review, the poor chemical stability of AAEM in high-pH and hightemperature environments is a critical issue that has prevented commercialization of AEMFC/AEMWE, since currently no AAEM exist which can stably operate in the high-pH and high-temperature environments of AEMFC/AEMWE [16]. Despite this,
AEMFC/AEMWEs have several promising benefits compared to PEMFC/PEMWEs, which is why research is actively addressing the issues impeding AAEM commercializing for AEMFC/AEMWE. Key benefits of AEMFC/AEMWE over PEMFC/PEMWE include:

- The ability to use cheaper non-platinum or nonprecious metal-based catalysts. In PEMFC/ PEMWE, the acidic environment requires the use of platinum catalysts and there is concern that widespread commercialization of these technologies will be hindered by insufficient platinum supply [24, 33]. In AEMFC, the alkaline environment permits more favourable oxygen reduction reaction kinetics, which allows for greater flexibility in selecting non-platinum or non-precious metal-based catalysts [16, 24, 25]. In AEMWE, the alkaline environment permits a greater variety of catalyst material selection, which could permit the use of non-precious metals for the hydrogen evolution and oxygen evolution reactions [33, 34].

- The ability to use a variety of fuels in fuel cells. In PEMFC, nitrogen-based fuels (e.g. hydrazine or ammonia) are not compatible with CEM and can severely deteriorate fuel cell performance even at $1 \mathrm{ppm}$ ammonia [25]. The alkaline environment in AEMFC has improved electro-oxidation kinetics which permits the use of a greater variety of liquid fuels including nitrogen-based fuels [24].

- The ability to use more concentrated fuels in fuel cells. Unlike PEMFC, in AEMFC, ions and water move in opposite directions. As Fig. 1 shows, water is both a reactant on the cathode side and product on the anode side [25]. Water transport across the IEM is by two predominant mechanisms: electro-osmotic drag and back diffusion. In electro-osmotic drag, when an $\mathrm{H}^{+}$or $\mathrm{OH}^{-}$ion passes through the IEM, it carries or "drags" a water molecule with it. In back diffusion, due to a concentration gradient between anode and cathode, water diffuses across the membrane to establish equilibrium [35, 36].

Interestingly, alkaline fuel cells, which are like AEMFC in that they rely on the transport of $\mathrm{OH}^{-}$ ions to generate electricity, were originally discovered in the 1930s by Francis T. Bacon; however, the main design shortcoming was the formation of carbonate precipitates (e.g. $\mathrm{K}_{2} \mathrm{CO}_{3(\mathrm{~s})}$ ) in the electrolyte solution (e.g. $\mathrm{KOH}$ ) [24]. Unlike AEMFC, the original 
alkaline fuel cell contained a liquid electrolyte solution and when air containing $\mathrm{CO}_{2}$ entered the fuel cell, it would react and form carbonates by the following reaction, which impeded fuel cell performance.

$\mathrm{CO}_{2}+\mathrm{H}_{2} \mathrm{O} \rightleftarrows \mathrm{H}_{2} \mathrm{CO}_{3} \rightleftarrows \mathrm{HCO}_{3}^{-}+\mathrm{H}^{+} \rightleftarrows \mathrm{CO}_{3}^{2-}+2 \mathrm{H}^{+}$.

Similarly, alkaline electrolysis, which utilizes an alkaline electrolyte (e.g. $\mathrm{KOH}$ ) to improve ionic conductivity and partake in the electrochemical reactions, is an established technology, but it faces a similar issue regarding electrode and membrane/diaphragm precipitates which reduce performance $[19,37]$. Electrolyte impurities such as calcium $\left(\mathrm{Ca}^{2+} /\right.$ $\left.\mathrm{Ca}(\mathrm{OH})_{2}\right)$ and magnesium $\left(\mathrm{Mg}^{2+} / \mathrm{Mg}(\mathrm{OH})_{2}\right)$ have very low solubility products, which can lead to precipitation in the high-pH environments [21].

By using an IEM, the cation head group is immobilized in the polymer matrix to minimize $\mathrm{CO}_{2}$ exposure and avoid the formation of carbonate precipitates in the AEMFC/AEMWE [2, 24, 38]. While no carbonate precipitates may form, AEMFC/AEMWE are sensitive to $\mathrm{CO}_{2}$ as $\mathrm{CO}_{2}$ ingress leads to a carbonation reaction between the ion-conducting group $\left(\mathrm{OH}^{-}\right)$in the membrane and $\mathrm{CO}_{2}$ in the air/water that converts the $\mathrm{OH}^{-}$to $\mathrm{HCO}_{3}{ }^{-} / \mathrm{CO}_{3}{ }^{2-}$ via the following reactions $[39,40]$ :

$\mathrm{CO}_{2}+\mathrm{OH}^{-} \rightleftarrows \mathrm{HCO}_{3}^{-}$

$\mathrm{HCO}_{3}^{-}+\mathrm{OH}^{-} \rightleftarrows \mathrm{CO}_{3}^{2-}+\mathrm{H}_{2} \mathrm{O}$.

Reduced AEMFC/AEMWE performance is attributed to this carbonation reaction which increases membrane resistance and also enables the adsorption of carbonates on the anode catalyst layer [16, 39, 41]. $\mathrm{CO}_{2}$ exposure to the AEM results in the carbonation reaction converting the ion-conducting group, a hydroxide ion, in the AEM to a larger carbonate ion which is four to five times less conductive compared to hydroxide [39, 42]. Current laboratory-scale strategies to minimize $\mathrm{CO}_{2}$ ingress include feeding pure oxygen or $\mathrm{CO}_{2}$-free air into fuel cells and degassing water supplies into water electrolysers; however, these are not practical solutions for largescale applications [39, 40]. By exploiting the selfpurge mechanism in AEMFC, it is postulated that improved $\mathrm{CO}_{2}$ tolerance can be achieved by operating at higher currents and also reverse the detrimental effects of $\mathrm{CO}_{2}$ ingress from operating at low currents [39]. In AEMFC, hydroxide is generated at the cathode and transported across the AEM to the anode. By operating at high currents, the hydroxide generation rate exceeds the carbonate formation rate, resulting in the excess hydroxide in the AEM purging the carbonate species $\left(\mathrm{HCO}_{3}{ }^{-}, \mathrm{CO}_{3}{ }^{2-}\right)$ from the membrane to the anode, thus allowing the AEM to remain in the $\mathrm{OH}^{-}$state and retain high conductivity [39, 43]. Modelling work by Krewer et al. [44] suggests that operating AEMFC at current densities greater than $1 \mathrm{~A} / \mathrm{cm}^{2}$ can significantly improve $\mathrm{CO}_{2}$ tolerance; however, this is awaiting experimental validation.

Additionally, recent work by Katayama et al. [41] has investigated feeding a gas blend (e.g. ammoniahydrogen) at the anode to facilitate a $\mathrm{HCO}_{3}{ }^{-}$consumption reaction and improving AEMFC $\mathrm{CO}_{2}$ tolerance. Katayama et al. [41] suggest that low $\mathrm{CO}_{2}$ tolerance in AEMFC is primarily due to carbonate species adsorbing on the hydrogen oxidation reaction catalyst at the anode, so by facilitating $\mathrm{HCO}_{3}{ }^{-}$consumption at the anode, it removes the adsorbed species and frees the catalyst to perform its function, thus retaining AEMFC performance. As Krewer et al. and Katayama et al. have shown, the area of AEMFC/AEMWE $\mathrm{CO}_{2}$ tolerance is rapidly evolving and shows great research potential to understand the carbonation mechanisms and mitigation strategies.

AEM research is primarily driven by the need to develop AAEMs for fuel cells and water electrolysis applications [13, 16, 45]. Literature has suggested that the primary AEM research objective is targeting AAEMs with higher anion conductivity and improved chemical and mechanical stability. A secondary research objective is identifying alternative non-platinum catalysts to reduce AEMFC/AEMWE costs. The first research objective is deemed most critical as without a stable AAEM, there is no need to develop non-platinum catalysts [25]. To address the first research objective, research has focused on two key areas, the anion exchange head group and polymer structure, and to a lesser extent, membrane preparation techniques [5].

Using the Web of Science (SCI-EXPANDED) database, an analysis of the number of journal article publications from 2001 to 2018 was performed to gauge research interest in AEMs. As Fig. 2 shows, the number of AEM publications has been growing steadily since 2008, indicating a growing interest in this research topic for the past 10 years. 


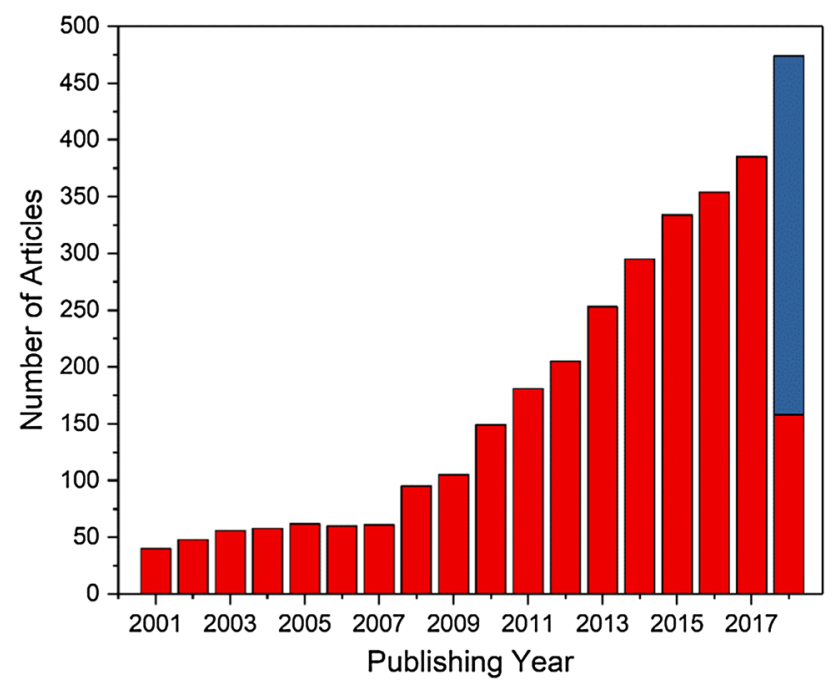

Figure 2 Annual journal article publications in anion exchange membranes (AEM), representing an average of $12 \%$ of annual ion exchange membrane journal article publications. The total number of articles for 2018 (blue) is a projection based on the number of articles published by April 2018 (red).

This review outlines advancements in anion exchange head groups, polymer structures and membrane preparation methods. Analytical methods to characterize AEM performance is also discussed to comment on limitations with current testing procedures.

\section{Synthesis of anion exchange membranes}

\section{Advancements in AEM head groups}

AEM head groups have traditionally been quaternary ammonium (QA) ions; however, current research is investigating other head groups such as tertiary diamines, phosphonium, sulphonium and metal cations $[2,5,16]$. Table 1 highlights common anionconducting cations found in AEM head groups. AEMs were first synthesized with QA because of their relatively easy preparation and good stability [46]. AEMs with QA can be formed by reacting the polymer containing a benzyl halide (e.g. chlorine) with an amine (e.g. triethylamine) to add the ammonia group, and then treating with an alkaline (e.g. potassium hydroxide) to convert the ammonia group to the salt form which can participate in anion exchange $[5,24]$. In terms of stability, QA has been shown to have higher thermal and chemical stability compared to quaternary phosphonium and tertiary sulphonium [46].

Additionally, the wide variety of tertiary amines permits the selection of diamines to act as both quaternization and cross-linking reagents when synthesizing AEMs. Notable tertiary diamine head groups include DABCO (1,4-diazabicyclo[2,2,2]octane) and TMHDA ( $N, N, N, N$-tetramethylhexane diammonium) [49]. The ability to self-cross-link is important since it simplifies the membrane synthesis process and improves membrane mechanical stability. To compensate for the intrinsically lower electrochemical mobility of $\mathrm{OH}^{-}$compared to $\mathrm{H}^{+}$, research has focused on increasing the ion exchange capacity (IEC) of AEM [16]. However, the trade-off is that higher IEC increases the membrane swelling and reduces mechanical stability [24]. By increasing crosslinking, it can mitigate, but not eliminate, these detrimental effects making these AEM good candidates for further development [64].

The main drawback of QA AEMs is poor chemical stability due to the ammonium group's susceptibility to $\mathrm{OH}^{-}$attack, leading to ammonium group degradation and reduced IEC [24]. The $\mathrm{OH}^{-}$attack occurs via one of the following reaction pathways: Hoffman elimination, nucleophile substitution $\left(S_{N} 2\right)$ or ylide intermediate formation [38, 46, 65]. Figure 3a-d highlights the respective degradation reaction pathways. Given that all these reactions can be initiated by nucleophiles such as $\mathrm{OH}^{-}$, the high-pH environment in AEMFC/AEMWE makes it inevitable that

Table 1 Common anion-conducting cations in AEM head group

\begin{tabular}{ll}
\hline Nitrogen-containing groups & Nitrogen-free groups \\
\hline Quaternary ammonium/tertiary diamines [2, 47-49] & Phosphonium [58, 59] \\
(Benz)Imidazolium [50-53] & Sulphonium [60, 61] \\
Guanidinium [54, 55] & Metal cations [62, 63] (Ruthenium, Nickel, Cobalt) \\
Pyridinium [56, 57] & \\
\hline
\end{tabular}


(a) Hoffman Elimination Mechanism

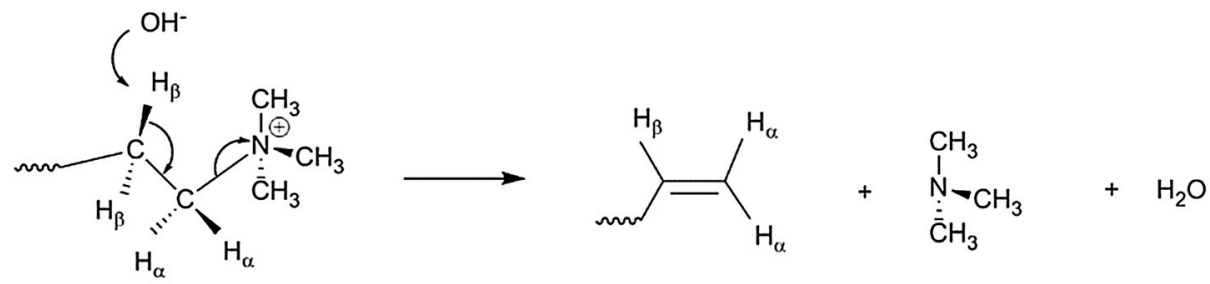

(b) Direct Nucleophile Substitution Mechanism - Pathway 1

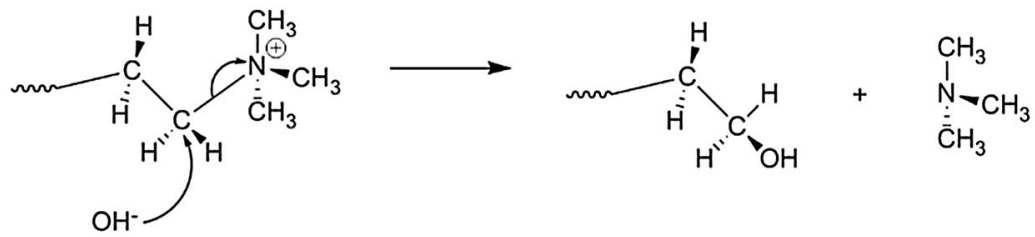

(c) Direct Nucleophile Substititon Mechanism - Pathway 2

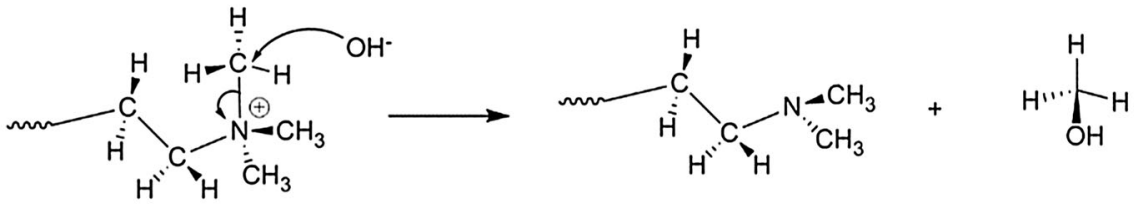

(d) Ylide Intermediate Mechanism



(e) Imidazolium Ring Opening Mechanism

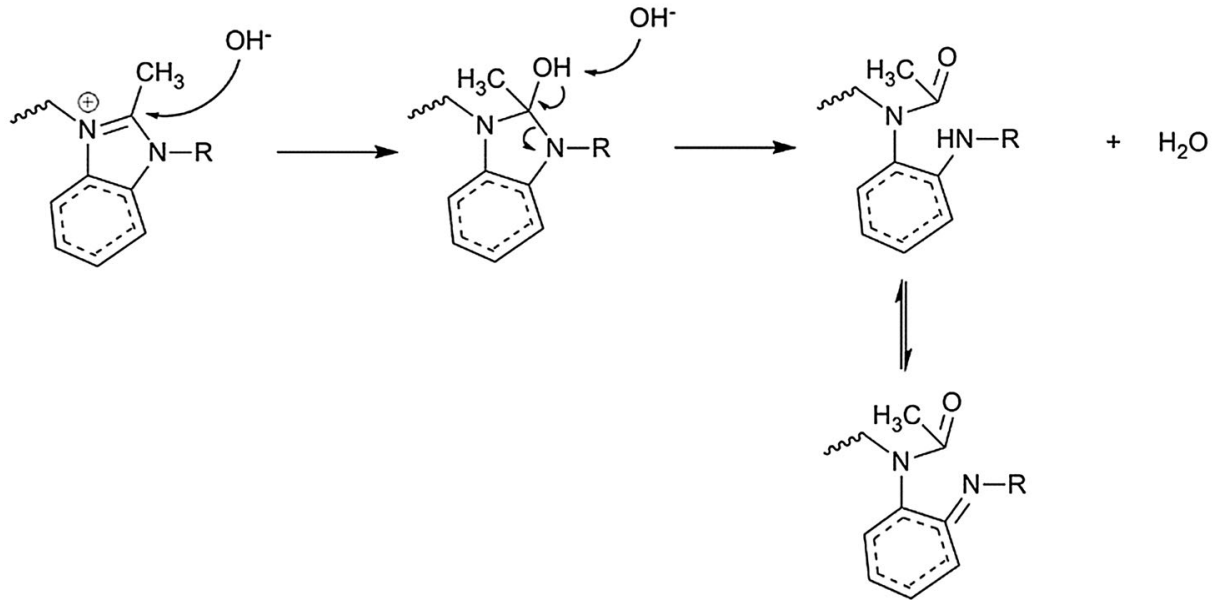

Figure 3 Nucleophile $\left(\mathrm{OH}^{-}\right)$degradation mechanisms for quaternary ammonium (a-d) and imidazolium (e) based ion-conducting groups. 
the QA will be degraded over time [2, 13]. It has been postulated that the cation chemical stability could be improved by adding large functional groups or electron-donating groups. Large functional groups (e.g. phenyl groups) create a steric hindrance effect that blocks the $\mathrm{OH}^{-}$from attacking the cation and electron-donating groups (e.g. methoxy groups) help protect the cation group from $\mathrm{OH}^{-}$attack $[5,51]$.

Branching out from QA head groups, researchers have investigated other nitrogen-containing cations such as guanidinium, imidazolium and pyridinium [50-52, 54-57]. Of these, imidazolium-based head groups have shown the most promise due to their relatively easy synthesis method, adaptable structure which allows for the addition of various functional groups and selective solubility in water-miscible solvents $[5,51,66]$. With respect to alkaline stability, in addition to $\mathrm{S}_{\mathrm{N}} 2$ and deprotonation degradation mechanisms, imidazolium-based head groups can also be degraded via a ring opening mechanism (Fig. 3e) [67, 68]. Multiple literature sources have reported that the electron-deficient $\mathrm{C} 2$ position of imidazolium-based head groups is highly susceptible to nucleophile attack, which could be mitigated through the addition of large functional groups to sterically hinder $\mathrm{OH}^{-}$attack [67, 69, 70]. There is some conflicting information as to the importance steric hindrance plays in protecting the $\mathrm{C} 2$ carbon. Price et al. [69] commented that imidazolium cation stability can be increased primarily by competing reversible deprotonation reactions, followed by electronic stabilization of the $\mathrm{C} 2$ carbon through resonance and finally by steric hindrance of the C2 carbon. The proposed predominant stabilizing mechanism is from the presence of acidic protons which the $\mathrm{OH}^{-}$attacks to deprotonate in a reversible reaction, therefore protecting the imidazolium nitrogen from being irreversibly degraded. Specifically, it was showed that imidazolium ions with a hydrogen at the $\mathrm{C} 2$ position was more stable than imidazolium ions with an isobutane group at the C2 position [69]. This conflicts with the theory that large electron dense functional groups at the C2 carbon would better stabilize the imidazolium cation, as shown by Wang et al. for imidazolium cations and by Thomas et al. for benzimidazolium cations [51, 70]. Additionally, Sun et al. summarized research done on large functional group substitutions for the N3, C4 and $\mathrm{C} 5$ positions of imidazolium cations, which all agreed with the trend of large electron dense functional groups improving imidazolium cation stability [71]. Of these substitutions, N3 substitutions are most promising as these imidazolium cations could be easily synthesized compared to C4- and C5substituted imidazolium cations [71]. From the imidazolium-based cation head groups, benzimidazolium cations (benzene group bound to an imidazolium group) have been shown to have improved stability, due to benzene ring resonance structures, and improved anion conductivity, due to ion cluster formation, compared to similar QA and imidazolium-based AEM [50]. As such, these head groups are promising and worthy of additional research.

Through understanding the impacts of steric hindrance and electron-donating groups, researchers have revisited phosphonium and sulphonium cations with a focus on adding large electron-donating groups surrounding the cation to improve chemical stability [5]. Phosphonium-based AEM can be synthesized in similar methods to QA AEMs, except they use phosphine instead of amine for quaternization. Research has shown that stable phosphonium- and sulphonium-based AEM can be synthesized through the addition of phenyl and methoxy groups to the phosphorous and sulphur group to protect the cations $[58,60]$. While this work is relatively recent, it has demonstrated that nitrogen-free AEM membranes can be synthesized, and suggests that further research is needed to improve phosphonium- and sulphonium-based AEM performance to match and/ or exceed nitrogen-based AEM performance.

A final class of AEM head groups involves metal cations such as ruthenium, cobalt and nickel [63]. The first metal cation-based AEM was synthesized using ruthenium, which was significant as it is a divalent cation which can carry two anions per cation, as opposed to all previous AEM cations which are monovalent [62]. Given the lower electrochemical mobility of $\mathrm{OH}^{-}$compared to $\mathrm{H}^{+}$, the ability to use multivalent cations can be a strategy to increase the IEC of AEM. Most recently, it has been found that nickel-based AEMs had the highest conductivity compared to ruthenium and cobalt-based AEMs, which suggests a new potential AEM head group and opportunity to explore other metals for AEM head groups [63].

Overall, there is no consensus on the "best" AEM head group as all head groups have inherent issues with chemical stability and limited IEC; however, 
there are promising head groups worthy of additional research. Imidazolium-based head groups, including benzimidazolium cations, are promising as stability and performance can be improved using large electron-donating functional groups. There has also been a focus on nitrogen-free AEM head groups, such as phosphonium, sulphonium, and metal cations, to investigate other materials that could be used in place of traditional QA cations in AEMs. While research into metal cation-based head groups is limited, this class of head groups shows great promise due to their high stability and high valency which can address AEM shortcomings related to chemical stability and low IEC.

In an ideal situation, the "best" AEM head group or membrane, is one that is both functional and practical. Functional in that it accomplishes the purpose of the given AEM application. This may include ensuring suitable ion exchange capacity and hydroxide conductivity, stable long-term operation, chemical stability and adequate mechanical properties for routine operation (continuous and/or intermittent). Functionality relates to the material, whereas practicality refers to the synthesis procedure for the head group/membrane. If this membrane is to be used in a commercial application, it will likely be manufactured at a large scale. Overly, complex membrane chemistries using multi-step synthesis with harsh chemicals and operating conditions requiring specialized equipment are not practical. Therefore, in designing the "best" AEM head group or membrane it is important to keep the end goal of the application in mind to engineer a cost-effective solution that will be functional and practical to use.

\section{Advancements in AEM polymer structure}

In parallel with enhancing AEM head groups, research also focuses on polymer structure to improve IEC and chemical stability [28, 46]. Since AEM have traditionally used QA groups, most work on AEM polymer structure involves polymers with QA, with benzyltrimethylammonium being considered the benchmark for AEM head groups [2]. Recently, it has been suggested that benzyl- $N$ methylpyrrolidinium should be considered the new QA benchmark in AEM research as it exhibits improved alkali stability, conductivity and in situ fuel cell performance compared to benzyltrimethylammonium [47]. As previously mentioned, there is a trade-off between increasing IEC, through the number of ion exchange sites, and decreasing mechanical stability due to water update and membrane swelling [24]. Therefore, AEM polymer research focuses on increasing polymer crosslinking and the formation of ion channels in polymers with distinct hydrophilic and hydrophobic regions [5]. This is driven in part by the success of Nafion ${ }^{\circledR}$ as a PEMFC membrane since it exhibits a "comb like" structure with a PTFE backbone and regularly spaced perfluorovinyl ether side chain terminated with a sulphonate group for ion exchange [72].

Cross-linking is done to impart more favourable thermal, mechanical and physiochemical properties on a polymer. It can be done as a cross-linking step in a polymerization reaction using high molecular weight or directly cross-linkable oligomers (one-step synthesis) or as a post-cross-linking step after polymerization (multi-step synthesis) [28, 46]. Most (post)cross-linking steps involve covalent bonding and the use of heat, radiation and/or chemicals to facilitate a cross-linking chemical reaction [73]. Given the variety of monomers used to synthesize AEMs, there is no universal cross-linking mechanism, but rather a variety of cross-linking and post-cross-linking reactions. To achieve easier and "greener" AEM synthesis, it is logical to expect that the one-step synthesis method is preferred compared to the postcross-linking route.

Polymer backbones are commonly polysulfones or fluorinated polymers [e.g. poly(vinylidene fluoride)] $[28,46]$. Figure 4 highlights common polymer backbone degradation pathways for polysulfones and fluorinated polymers. Polysulfones are susceptible to ether hydrolysis and quaternary carbon hydrolysis due to hydroxide attack, while fluorinated polymers are susceptible to dehydrofluorination [74-78]. Therefore, in addition to AEM head group alkaline degradation, AEM chemical stability is also affected by the polymer backbone design. Within these classes of polymers, chemical modifications have allowed more thermal and chemically stable polymer backbones to be designed and/or selected [79-81].

Inspired by Nafion ${ }^{\circledR}$, rather than just having the QA attached to the polymer backbone, polymers were created with regularly spaced flexible side chains containing one or multiple QA groups [5, 82]. Small improvements in stability were seen by 




Figure 4 Polymer degradation pathways for polysulfone (top) and poly(vinylidene fluoride), PVDF (bottom).

changing the polymer backbone to less polar polymers; however, the greatest stability improvements were achieved by attaching the QA groups by a long aliphatic side chain [83]. By grafting multiple QA groups on the side chains, regions of hydrophobicity (polymer backbone) and hydrophilicity (polymer side chains) developed which has been shown to improve IEC and chemical stability [84, 85]. It has been reported that AEM with $99 \mathrm{mS} / \mathrm{cm} \mathrm{OH}^{-}$conductivity at room temperature have been synthesized, which is greater than conductivity values reported for Nafion ${ }^{\circledR}$ [82].

Strategies to obtain AEM with ion channels include locating ion-conducting groups at the ends of polymer side chains, synthesizing polymer main chains using multiblock co-polymers containing regions of ion-conducting groups [86, 87], monomers with densely functionalized ion-conducting regions on the main chains [88] or separately attaching the hydrophobic side change and ion-conducting group to the polymer backbone [89]. Work by Pan et al. and Weiber et al. shows that increasing the number of QA groups in the block copolymer or the hydrophobic side chain length improved the membrane's IEC to a certain point, after which the IEC decreased with additional QA groups or chain length [86, 89]. This was likely due to the QA group proximity (limited ion-dissociating ability) and the over-assembly of ion clusters that resulted in separate ion-conducting regions.

This demonstrates the need for "rational polymer architecture" to optimize the location, type and concentration of anion-conducting groups and hydrophobic side chains to achieve optimal AEM performance through effective hydrophobic/hydrophilic region interactions. In Fig. 5, the B scenario is what has been shown to be most effective as it creates ion channels to facilitate higher anion conductivity while providing improved alkaline stability since the polymer backbone is protected in the hydrophobic region [89].

Another factor to consider when synthesizing IEMs is Manning's counterion condensation theory, which suggests that counterions can condense on polyelectrolytes if the linear charge density of the polyelectrolyte chain is greater than one [90, 91]. Due to counterion condensation, reduced effective charge is seen compared to expected values from elemental analysis since the counterion is effectively "screening" the polyelectrolyte charge [92]. While minimal 


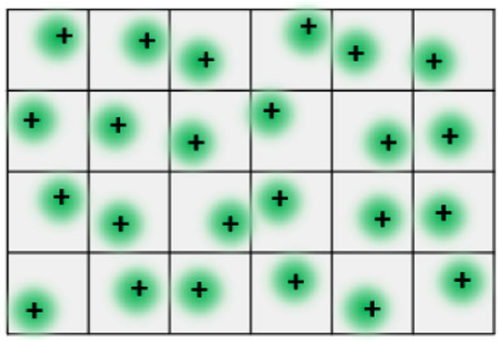

(a)

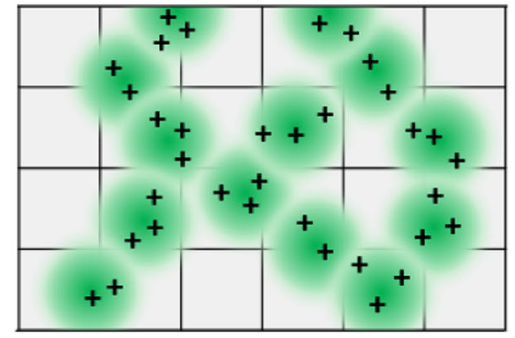

(b)

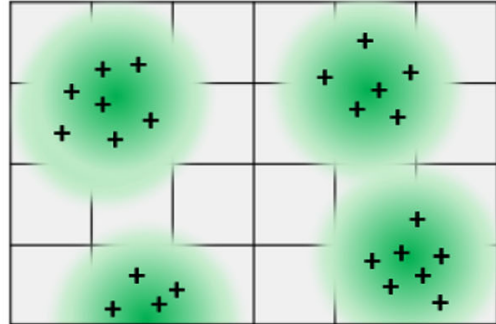

(c)

AEM Functional Groups

Figure 5 Development of ion channels in AEM. a Dispersed and underdeveloped ion channels, $\mathbf{b}$ interconnected ion channels conductive to the formation of "ionic highways", c segregated

research has investigated this effect in AEMs, multiple sources have demonstrated and modelled the significance of this effect for sulphonated CEMs [92-94]. For example, Nafion ${ }^{\circledR} 117$ has been reported to have approximately $80 \%$ of protons in the condensed state [94]. As research targets improvements in ion exchange capacity, understanding and mitigating the effect of counterion condensation can provide an opportunity for optimized IEM polymer and membrane structures.

\section{Advancements in AEM preparation methods}

In terms of membrane synthesis, most AEMs are homogenous membranes prepared by (a) direct polymerization and cross-linking, (b) chemical modification of polymers by irradiation or grafting or (c) chemical reactions to modify polymers [46]. This usually involves phase inversion methods where solutions of membrane precursors are dissolved in polar solvents and casts on a plate after which the solvent is evaporated producing an IEM [5]. Typically, there are multiple steps with harsh solvents (e.g. chloromethyl methyl ether which is carcinogenic for chloromethylation) or radiation sources (e.g. UV, gamma or X-ray for grafting various head groups) $[46,95]$.

Alternatively, heterogeneous AEM can be prepared using (a) a pore filling or pore immersion technique which synthesizes polymeric membranes on a porous support or (b) mixed matrix membranes that fix inorganic nanoparticles in organic polymers [5]. Pore filling and pore immersion are similar

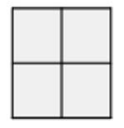

Hydrophobic Polymer Matrix

overdeveloped ion channels with distinct hydrophilic/hydrophobic regions. Adapted from [89].

techniques in that a polymer solution is either poured over or immersed in a porous substrate allowing the polymer matrix to fill the porous substrate pores creating a membrane [96-99]. The porous substrate is selected to be chemically inert and mechanically stable (e.g. high-density polyethylene, polypropylene, polystyrene, polyimide or similar porous polyolefin) [5]. This technique combines the beneficial characteristics of the polymer (high ion conductivity) and porous support (mechanical strength and reduced membrane swelling) to produce membranes with improved performance [100]. While this method may involve repeated pouring and immersion steps, the literature sources have reported the ability to obtain both cation and anion exchange membranes with high IEC [97, 98, 101]. Work by Lee et al. [98] relating to anion exchange membranes is significant as AEM with high IEC were achieved without significant membrane swelling, which was attributed to the use of the porous substrate. This produced membranes with improved mechanical strength compared to similar AEMs synthesized without porous supports. Additionally, by using a porous support, AEMs could be synthesized with multiple narrow ion channels that allowed for the high $\mathrm{OH}^{-}$ conductivity [98].

Mixed matrix membranes are another promising type of heterogeneous membranes due to the variety of inorganic nanoparticles and organic polymers that can be blended to achieve desired membrane characteristics [102]. Examples of inorganic nanoparticles that have been used include metal ions, metal oxides, silica, functionalized nanoparticles (e.g. imidazoliumfunctionalized silsesquioxane), graphene oxide and 
carbon nanotubes [48, 53, 102-104]. The inorganic phase is selected to provide improved ion conductivity and thermal, chemical and mechanical stability, while the organic phase is selected to provide the flexibility to the membrane [5, 102]. Sol-gel techniques are typically used to prepare mixed matrix membranes, which stresses the importance of welldispersed inorganic nanoparticles in the organic phase to produce uniform membranes [105]. Heterogeneous membranes synthesized using porous supports or inorganic nanoparticles are promising methodologies to achieve AEM with high IEC without compromising mechanical strength. This methodology still uses volatile organic solvents, which suggests further research is needed to develop IEM synthesis pathways that can minimize harsh solvent usage. With the variety of porous supports and inorganic nanoparticles available, ample research opportunities are available to tune membrane properties for various applications.

\section{Characterization of anion exchange membranes}

AEM characterization methods primarily examine the chemical homogeneity, structure, stability and mechanical properties [106, 107]. Analytical methods such as microscopy [scanning electron microscopy (SEM)] and spectroscopy [energy-dispersive X-ray (ERD), nuclear magnetic resonance (NMR), Fouriertransformed infrared (FTIR), small-angle X-ray scattering (SAXS)] are used to characterize the molecular composition (e.g. uniform distribution of head groups, formation of ion clusters) and structure of the membrane surfaces (e.g. pore structure, surface smoothness) [89, 101]. If asymmetrical membranes are synthesized, comparisons can be made between both membrane surfaces to understand the impact surface differences have on membrane properties.

AEM performance and chemical stability are typically assessed by measuring the IEC, swelling ratio, water uptake, water content, contact angle, conductivity and alkaline stability [2, 28, 108].

\section{Ion exchange capacity (IEC)}

The IEC is a measure of the number of exchangeable ions per membrane dry weight (meqiv/g or mmol/g) [106]. It can be measured via different methods including titration, spectroscopy to determine $\mathrm{NO}_{3}{ }^{-}$ ion concentrations and ion selective electrodes (e.g. $\mathrm{pH}$ probe) to determine the presence of $\mathrm{H}^{+} / \mathrm{OH}^{-}$ ions in solution [109]. Titration methods, either through acid/base titration or the Mohr method, are the most common methods to determine IEC. From a safety perspective, the acid/base titration method may be preferred since the Mohr method involves hexavalent chromium $\left(\mathrm{CrO}_{4}{ }^{2-}\right)$ which is a known carcinogen [110, 111]; however, it has been postulated that there are inherent shortcomings with the acid/ base titration method related to $\mathrm{CO}_{2}$ poisoning of the $\mathrm{OH}^{-}$groups. When the AEM in $\mathrm{OH}^{-}$form is exposed to $\mathrm{CO}_{2}$-containing environments (e.g. ambient air or air-saturated water), these groups can convert to $\mathrm{HCO}_{3}{ }^{-}$form and alter the calculated IEC [109]. This influence may be minimal given the short exposure time to air, yet Karas et al. [109] demonstrated IEC decreases of 3.5 and $2.0 \%$ per minute for homogeneous and heterogeneous AEMS, respectively, when exposed to air for $5 \mathrm{~min}$. Therefore, efficient procedures when performing acid/base titrations and rinsing AEMs with degassed DI water could help mitigate, but not eliminate, the risk of $\mathrm{CO}_{2}$ poisoning when measuring IEC [109, 112].

Furthermore, it has been suggested to measure the membrane IEC in the $\mathrm{Cl}^{-}$form, which is the form the membrane is typically synthesized in, to eliminate any deviations in IEC measurements due to $\mathrm{pH}$ swings during acid/base titrations [2]. To measure the AEM IEC in $\mathrm{Cl}^{-}$form, the AEM is initially equilibrated in a $\mathrm{NaNO}_{3}$ solution and then acidified using $\mathrm{HNO}_{3}$. The resulting solution containing the displaced $\mathrm{Cl}^{-}$ions is then titrated with $\mathrm{AgNO}_{3}$ using Ag-titrodes to the endpoint, which is when all $\mathrm{Cl}^{-}$ has been converted to $\mathrm{AgCl}$. Using the following equation, where $\mathrm{m}_{\mathrm{d}}$ is the membrane dry mass, which is the membrane mass after drying at $80{ }^{\circ} \mathrm{C}$ for $48 \mathrm{~h}$ until there is no change in membrane mass, the IEC $\left(\mathrm{Cl}^{-}\right.$form $)$can be determined $[47,113]$ :

$\mathrm{IEC}=\frac{V_{\mathrm{AgNO}_{3}} * C_{\mathrm{AgNO}_{3}}}{m_{\mathrm{d}}}$.

For the acid/base titration method, various procedures are reported depending on acid/base strengths used and soaking times. The general premise is to soak the AEM in a strong base solution (e.g. $1 \mathrm{M}$ $\mathrm{NaOH})$ to convert the AEM to the $\mathrm{OH}^{-}$form and then soaking in a strong acid solution of known volume and concentration to convert the AEM to the 
$\mathrm{Cl}^{-}$form. Then, the AEM is removed and rinsed with DI water so the resulting diluted $\mathrm{HCl}$ solution is titrated with standardized $\mathrm{NaOH}$ to the phenolphthalein endpoint. To calculate the number of exchangeable ions $\left(\mathrm{OH}^{-}\right)$present, the moles of $\mathrm{NaOH}$ added are subtracted from the moles of $\mathrm{HCl}$ added. This value is then divided by the membrane dry mass, and the resulting IEC calculated by the acid/ base titration method is $[66,70]$ :

IEC $=\frac{\left(V_{\text {acid }} * C_{\text {acid }}\right)-\left(V_{\text {base }} * C_{\text {base }}\right)}{m_{\mathrm{d}}}$.

With the Mohr method, an AEM is converted to the $\mathrm{Cl}^{-}$form by soaking in a salt solution (e.g. $1 \mathrm{M} \mathrm{NaCl}$ ). The AEM is then rinsed and equilibrated in a $0.5 \mathrm{M}$ $\mathrm{Na}_{2} \mathrm{SO}_{4}$ solution to facilitate the release of $\mathrm{Cl}^{-}$. Using a $\mathrm{AgNO}_{3}$ solution with $\mathrm{K}_{2} \mathrm{CrO}_{4}$ indicator, the AEM/ $\mathrm{Na}_{2} \mathrm{SO}_{4}$ solution is titrated until the $\mathrm{K}_{2} \mathrm{CrO}_{4}$ endpoint, which indicates when all the chlorides have been precipitated and now $\mathrm{Ag}_{2} \mathrm{CrO}_{4}$ forms. The resulting IEC calculated by the Mohr method is [110, 114]:

IEC $=\frac{\left(V_{\mathrm{AgNO}_{3}} * C_{\mathrm{AgNO}_{3}}\right)}{m_{\mathrm{d}}}$.

As with any titration, there are inherent human errors in determining the colour change at the endpoint, which ultimately affects the calculated IEC. A further complication for titrations is the dilute nature of the ion of interest targeted in the titrations. To ensure complete conversion of the AEM to the given form, strong bulk solutions (e.g. $\mathrm{HCl}, \mathrm{NaSO}_{4}$ ) are needed for the titrations. For both the acid/base titration and Mohr method, the concentration of the ion participating in the ion exchange is low relative to the bulk solution, resulting in challenges to accurately determine the endpoint when titrating. To improve accuracy and reduce variability when performing titrations, it is possible to use an ISE (e.g. $\mathrm{pH}$ probe) to determine the endpoint rather than relying on the visual colour change [109].

Unlike determining IEC for CEM, IEC procedures for AEM are less well defined. While the most common IEC procedures involve titrations, this may not be the most accurate method. Karas et al. [109] demonstrated that using UV-Vis spectroscopy to determine the $\mathrm{NO}_{3}{ }^{-}$ions that exchange with $\mathrm{Cl}^{-}$ions in an AEM produced IEC results in greatest agreement with theoretical IEC determined from elemental analysis of AEM composition. By understanding and mitigating the shortcomings with the different IEC procedures, it is possible to reduce the resulting errors in IEC values obtained. More importantly, this demonstrates a need to develop a robust and universal IEC measurement procedure for AEMs to allow accurate comparisons between different AEMs.

\section{Swelling ratio (SR)}

The swelling ratio is a measure of the linear expansion of the membranes when exposed to water [115]. It is calculated as a per cent difference between wet and dry membrane lengths. The "dry" membrane state is defined the same as above for IEC.

$\mathrm{SR}=\frac{l_{\mathrm{w}}-l_{\mathrm{d}}}{l_{\mathrm{d}}} * 100 \%$.

\section{Water uptake (WU)}

The water uptake is a measure of how the membrane mass changes when exposed to water [116]. It is calculated as a per cent difference between wet and dry membrane masses. The "dry" membrane state is defined the same as above for IEC.

$\mathrm{WU}=\frac{m_{\mathrm{w}}-m_{\mathrm{d}}}{m_{\mathrm{d}}} * 100 \%$.

\section{Membrane water content $(\gamma)$}

The membrane water content is a measure of the number of water molecules per mobile anion and is calculated by dividing the water uptake by the molecular weight of water and IEC [117]. Note that the WU is multiplied by 10 to account for the WU being reported in per cent and the IEC being reported in $\mathrm{mmol} / \mathrm{g}$.

$\gamma=\frac{10 * \mathrm{WU}}{\mathrm{MW}_{\mathrm{H}_{2} \mathrm{O}} * \mathrm{IEC}}$.

\section{Water contact angle $(\theta)$}

The water contact angle $(\theta)$ is a measure of the wettability of a membrane surface with large contact angles indicating highly hydrophobic surfaces. This can be measured using the sessile-drop technique [101]. 


\section{Hydroxide conductivity $(\sigma)$}

Hydroxide conductivity can be calculated from electrochemical impedance spectroscopy (EIS) and a twoor four-electrode testing cell [118]. After soaking an AEM in DI water overnight, the membrane is secured in the testing cell and varying AC current is applied to collect impedance data. Using nonlinear least squares regression analysis, the membrane ionic resistance $\left(R_{\mathrm{m}}\right)$ can be obtained and from that the conductivity $(\sigma)$ can be calculated from the following [70, 119]:

$\sigma=\frac{L}{R_{\mathrm{m}} * A}$.

Given that the aforementioned procedure is performed in ambient atmosphere, the presence of $\mathrm{CO}_{2}$ presents challenges when measuring the true $\mathrm{OH}^{-}$ conductivity due to the rapid formation of carbonates and bicarbonates (refer to Eq. 1) [31, 120]. This effect was previously believed to be minimal; however, $\mathrm{Ziv}$ et al. [31] have shown that $\mathrm{CO}_{2}$ can significantly impact true $\mathrm{OH}^{-}$conductivity measurements ( $\sim 50 \mathrm{mS} / \mathrm{cm}$ (conventional procedure) versus 103 $\mathrm{mS} / \mathrm{cm}\left(\mathrm{CO}_{2}\right.$-free environment). Ziv et al. proposes modifying conventional hydroxide conductivity testing procedure to ensure a $\mathrm{CO}_{2}$-free environment by subjecting the AEM to a nitrogen sweep gas flow in the testing cell. Then, a current is applied to generate $\mathrm{OH}^{-}$at the cathode and convert (bi)carbonates to $\mathrm{CO}_{2}$ which are released at the anode. Once all the $\mathrm{CO}_{2}$ is released, the AEM would be in the pure $\mathrm{OH}^{-}$ form allowing for true $\mathrm{OH}^{-}$conductivities to be measured and thus providing a standardized platform to compare hydroxide conductivity measurements between various AEMs [31].

\section{Alkaline stability}

The alkaline stability is a measure of how the AEM performance changes over time when exposed to high-pH environments [116]. Testing conditions vary; however, the general premise is to soak the AEM in a high-pH solution (e.g. 1-10 M KOH) at a given temperature (room temperature or elevated temperature) for extended periods of time and periodically testing the membrane IEC to see how it changes with time [70]. Inconsistencies in alkaline stability testing conditions may be problematic, as it's been shown that alkaline stability is influenced by the hydration level of the nucleophile $\left(\mathrm{OH}^{-}\right)$; specifically, reducing hydration levels reduces alkaline stability [121]. At higher hydration levels, the water molecules fill the solvation sphere surrounding the $\mathrm{OH}^{-}$, in effect shielding it and reducing its nucleophilic character, resulting in improved alkaline stability. Ex situ alkaline stability has been tested using $\mathrm{KOH}$ or $\mathrm{NaOH}$ solutions up to $10 \mathrm{M}$, which corresponds to a water content of approximately $5 \quad(\gamma=5)$ $[66,121,122]$. Higher $\mathrm{KOH}$ concentrations have lower water contents; however, the higher viscosities may adversely affect $\mathrm{OH}^{-}$diffusivity and resulting measured alkaline stability. In AEMFCs, as Fig. 1 shows, the cathode can become water-depleted, especially at higher current densities, thus exposing the AEM to ultralow hydration levels $(\gamma=0)$. Work by Dekel et al. demonstrated that QA groups had excellent stability at $\gamma=4$; however, this stability was significantly reduced at $\gamma=0$, which was attributed to the change in $S_{N} 2$ reaction energies, which was the predominant degradation mechanism for the QA group studied [121]. As the hydration level increased, the $\mathrm{OH}^{-}$ nucleophilicity decreased, resulting in higher activation energies and reaction energies. This demonstrates that current ex situ alkalinity stability testing using aqueous solutions may produce artificially high alkalinity stability values that would not be representative of in situ alkaline stability in AEMFC. Therefore, Dekel et al. [121] proposed an alternative ex situ alkalinity stability testing procedure using NMR and water-free hydroxide (crown ether/KOH) solution where the water $/ \mathrm{OH}^{-}$ratio $(\gamma)$ could be controlled to assess alkaline stability at different hydration levels.

To analyse AEM mechanical properties, properties such as thermal stability and tensile strength are measured. Knowing the elevated operating temperatures of AEMFC (up to $200{ }^{\circ} \mathrm{C}$ ) and AEMWE (typically $50-70{ }^{\circ} \mathrm{C}$ ), thermal stability of the membrane is important and can be determined using thermogravimetric analysis (TGA) and differential scanning calorimetry (DSC) [13, 101, 123]. TGA is used to assess thermal stability by monitoring the temperature at which membrane changes occurs due to water loss, head group decomposition and/or polymer decomposition [30, 123, 124]. DSC can be used to evaluate the glass transition temperature, the effects of thermal cycling and changes in polymer crystallinity and cross-linking [112, 123-125]. By stretching membrane samples in a universal testing 
machine, various physical properties like tensile strength, stress-strain curves and elongation at break can be determined [103, 116, 125].

\section{Conclusions}

AEM research is driven by the need to develop AAEM for fuel cells and water electrolysis applications since presently there are no suitable AAEMs which can stably operate in the high-pH and hightemperature environments of AEMFC/AEMWE. AEMFC/AEMWE are a promising source of clean energy and have several operational benefits compared to PEMFC/PEMWE, mainly in that catalysts can be platinum free. Given the limited focus on AEM compared to CEM, it is a matter of time before suitable AAEMs for AEMFC/AEMWE are developed.

The principal AEM research objective is to improve AEM chemical and mechanical stability in high-pH and high-temperature environments. To achieve this, research is focused on improving AEM head groups, polymer structure and membrane preparation methods to produce AEM with high IEC and conductivity, improved alkaline stability and improved mechanical stability to permit the commercialization of AEMFC/ AEMWE. Given that no suitable AEM has been synthesized to achieve these performance objectives reliably, it demonstrates the need for further research in this field. Progress has been made in using imidazole and metal cation-based head groups to improve IEC and conductivity. Additionally, using "rational polymer architecture" to design polymer backbones, several AEMs have been synthesized with ion channels that have demonstrated high IEC and conductivity and improved $\mathrm{OH}^{-}$stability due to the formation of hydrophobic and hydrophilic regions in the membrane. Finally, heterogeneous membrane preparation techniques (e.g. pore-filled/immersed membranes, mixed matrix membranes) are promising methodologies to tune membrane characteristics by optimizing the ratio of polymer to porous support or nanoparticles.

While there have been developments of nitrogenfree and metal cation-based AEM head groups, research on polymer structure and membrane preparation methods continue to focus on AEM with QA head groups. In conjunction with the principle AEM research objective, future research should investigate consolidating advancements in AEM head groups with an optimized polymer structure in heterogeneous membranes. This could bring together the valuable characteristics gained from using a novel head group with improved chemical stability, with the benefits of a polymer structure with ion channels and improved membrane properties from using a porous support or inorganic nanoparticles.

\section{Acknowledgements}

B.P.L. gratefully acknowledges financial support from Imperial College London (ICL). S.J. gratefully acknowledges financial support from the Department of Chemical Engineering at ICL. K.F.L.H. gratefully acknowledges financial support from the Department of Chemical Engineering at ICL and Statoil.

\section{Compliance with ethical standards}

Conflict of interest The authors declare that they have no conflict of interest.

Open Access This article is distributed under the terms of the Creative Commons Attribution 4.0 International License (http://creativecommons.org/ licenses/by/4.0/), which permits unrestricted use, distribution, and reproduction in any medium, provided you give appropriate credit to the original author(s) and the source, provide a link to the Creative Commons license, and indicate if changes were made.

\section{References}

[1] Peterson DS (2014) Ion exchange membranes. In: Li D (ed) Encyclopedia of microfluidics and nanofluidics. Springer, Boston, MA

[2] Varcoe JR, Atanassov P, Dekel DR et al (2014) Anionexchange membranes in electrochemical energy systems. Energy Environ Sci 7:3135-3191. https://doi.org/10.1039/ C4EE01303D

[3] $\mathrm{Xu} \mathrm{T}$ (2005) Ion exchange membranes: state of their development and perspective. J Membr Sci 263:1-29. https://doi.org/10.1016/j.memsci.2005.05.002

[4] Strathmann H (2010) Electrodialysis, a mature technology with a multitude of new applications. Desalination 264:268-288. https://doi.org/10.1016/j.desal.2010.04.069 
[5] Ran J, Wu L, He Y et al (2017) Ion exchange membranes: new developments and applications. J Membr Sci 522:267-291. https://doi.org/10.1016/j.memsci.2016.09. 033

[6] Strathmann H, Grabowski A, Eigenberger G (2013) Ionexchange membranes in the chemical process industry. Ind Eng Chem Res 52:10364-10379. https://doi.org/10.1021/ ie4002102

[7] Ben Hamouda S, Touati K, Ben Amor M (2012) Donnan dialysis as membrane process for nitrate removal from drinking water: membrane structure effect. Arab J Chem. https://doi.org/10.1016/j.arabjc.2012.07.035

[8] Rozanska A, Wisniewski J, Winnicki T (2006) Donnan dialysis with anion-exchange membranes in a water desalination system. Desalination 198:236-246. https://doi. org/10.1016/j.desal.2006.02.006

[9] Akretche DE, Kerdjoudj H (2000) Donnan dialysis of copper, gold and silver cyanides with various anion exchange membranes. Talanta 51:281-289. https://doi.org/ 10.1016/S0039-9140(99)00261-1

[10] Fonseca AD, Crespo JG, Almeida JS, Reis MA (2000) Drinking water denitrification using a novel ion-exchange membrane bioreactor. Environ Sci Technol 34:1557-1562. https://doi.org/10.1021/es9910762

[11] Fox S, Oren Y, Ronen Z, Gilron J (2014) Ion exchange membrane bioreactor for treating groundwater contaminated with high perchlorate concentrations. J Hazard Mater 264:552-559. https://doi.org/10.1016/j.jhazmat.2013.10. 050

[12] Matos CT, Sequeira AM, Velizarov S, Reis MA (2009) Nitrate removal in a closed marine system through the ion exchange membrane bioreactor. J Hazard Mater 166:428-434. https://doi.org/10.1016/j.jhazmat.2008.11. 038

[13] Vincent I, Bessarabov D (2018) Low cost hydrogen production by anion exchange membrane electrolysis: a review. Renew Sustain Energy Rev 81:1690-1704. https:// doi.org/10.1016/j.rser.2017.05.258

[14] Zlotorowicz A, Strand RV, Burheim OS et al (2017) The permselectivity and water transference number of ion exchange membranes in reverse electrodialysis. J Membr Sci 523:402-408. https://doi.org/10.1016/j.memsci.2016. 10.003

[15] Leong JX, Daud WRW, Ghasemi M et al (2013) Ion exchange membranes as separators in microbial fuel cells for bioenergy conversion: a comprehensive review. Renew Sustain Energy Rev 28:575-587. https://doi.org/10.1016/j. rser.2013.08.052

[16] Gottesfeld S, Dekel DR, Page M et al (2017) Anion exchange membrane fuel cells: current status and remaining challenges. J Power Sources 375:170-184. https://doi.org/ 10.1016/j.jpowsour.2017.08.010

[17] Marini S, Salvi P, Nelli P et al (2012) Advanced alkaline water electrolysis. Electrochim Acta 82:384-391. https:// doi.org/10.1016/j.electacta.2012.05.011

[18] Varcoe JR, Slade RCT (2005) Prospects for alkaline anionexchange membranes in low temperature fuel cells. Fuel Cells 5:187-200. https://doi.org/10.1002/fuce.200400045

[19] Ursua A, Gandia LM, Sanchis P (2012) Hydrogen production from water electrolysis: current status and future trends. Proc IEEE 100:410-426. https://doi.org/10.1109/ JPROC.2011.2156750

[20] Santos DMF, Sequeira CAC, Figueiredo JL (2013) Hydrogen production by alkaline water electrolysis. Quim Nova 36:1176-1193. https://doi.org/10.1590/S010040422013000800017

[21] Zeng K, Zhang D (2010) Recent progress in alkaline water electrolysis for hydrogen production and applications. Prog Energy Combust Sci 36:307-326. https://doi.org/10.1016/j. pecs.2009.11.002

[22] Leng Y, Chen G, Mendoza AJ et al (2012) Solid-state water electrolysis with an alkaline membrane. J Am Chem Soc 134:9054-9057. https://doi.org/10.1021/ja302439z

[23] Antolini E, Gonzalez ER (2010) Alkaline direct alcohol fuel cells. J Power Sources 195:3431-3450. https://doi.org/ 10.1016/j.jpowsour.2009.11.145

[24] Arges CG, Ramani V, Pintauro PN (2010) Anion exchange membrane fuel cells. Elctrochem Soc Interface 19:31-35. https://doi.org/10.3384/ecp110571227

[25] Dekel DR (2018) Review of cell performance in anion exchange membrane fuel cells. J Power Sources 375:158-169. https://doi.org/10.1016/j.jpowsour.2017.07. 117

[26] Carmo M, Fritz DL, Mergel J, Stolten D (2013) A comprehensive review on PEM water electrolysis. Int J Hydrog Energy 38:4901-4934. https://doi.org/10.1016/j.ijhydene. 2013.01.151

[27] Sone Y (1996) Proton conductivity of Nafion 117 as measured by a four-electrode AC impedance method. J Electrochem Soc 143:1254-1259. https://doi.org/10.1149/ 1.1836625

[28] Merle G, Wessling M, Nijmeijer K (2011) Anion exchange membranes for alkaline fuel cells: a review. J Membr Sci 377:1-35. https://doi.org/10.1016/j.memsci.2011.04.043

[29] Zheng Y, Ash U, Pandey RP et al (2018) Water uptake study of anion exchange membranes. Macromolecules. https://doi.org/10.1021/acs.macromol.8b00034

[30] Li Z, He X, Jiang Z et al (2017) Enhancing hydroxide conductivity and stability of anion exchange membrane by blending quaternary ammonium functionalized polymers. 
Electrochim Acta 240:486-494. https://doi.org/10.1016/j. electacta.2017.04.109

[31] Ziv N, Dekel DR (2018) A practical method for measuring the true hydroxide conductivity of anion exchange membranes. Electrochem Commun 88:109-113. https://doi.org/ 10.1016/j.elecom.2018.01.021

[32] Dekel DR, Rasin IG, Page M, Brandon S (2018) Steady state and transient simulation of anion exchange membrane fuel cells. J Power Sources 375:191-204. https://doi.org/10. 1016/j.jpowsour.2017.07.012

[33] Seh ZW, Kibsgaard J, Dickens CF et al (2017) Combining theory and experiment in electrocatalysis: insights into materials design. Science 355:eaad4998. https://doi.org/10. 1126/science.aad4998

[34] Seitz LC, Hersbach TJP, Nordlund D, Jaramillo TF (2015) Enhancement effect of noble metals on manganese oxide for the oxygen evolution reaction. J Phys Chem Lett 6:4178-4183. https://doi.org/10.1021/acs.jpclett.5b01928

[35] Huo S, Deng H, Chang Y, Jiao K (2012) Water management in alkaline anion exchange membrane fuel cell anode. Int J Hydrog Energy 37:18389-18402. https://doi.org/10. 1016/j.ijhydene.2012.09.074

[36] Spiegel C (2007) Designing and building fuel cells. McGraw Hill Professional, New York

[37] Ayers KE, Anderson EB, Capuano C et al (2010) Research Advances towards low cost, high efficiency PEM electrolysis. ECS Trans 33:3-15

[38] Slade RCT, Kizewski JP, Poynton SD et al (2012) Encyclopedia of sustainability science and technology. https:// doi.org/10.1007/978-1-4419-0851-3

[39] Ziv N, Mustain WE, Dekel DR (2018) Review of ambient $\mathrm{CO}_{2}$ effect on anion exchange membranes fuel cells. Chemsuschem. https://doi.org/10.1002/cssc.201702330

[40] Parrondo J, Arges CG, Niedzwiecki M et al (2014) Degradation of anion exchange membranes used for hydrogen production by ultrapure water electrolysis. RSC Adv 4:9875-9879. https://doi.org/10.1039/c3ra46630b

[41] Katayama Y, Yamauchi K, Hayashi K et al (2017) Anionexchange membrane fuel cells with improved $\mathrm{CO}_{2}$ tolerance: impact of chemically induced bicarbonate ion consumption. ACS Appl Mater Interfaces 9:28650-28658. https://doi.org/10.1021/acsami.7b09877

[42] Marino MG, Melchior JP, Wohlfarth A, Kreuer KD (2014) Hydroxide, halide and water transport in a model anion exchange membrane. J Membr Sci 464:61-71. https://doi. org/10.1016/j.memsci.2014.04.003

[43] Suzuki S, Muroyama H, Matsui T, Eguchi K (2013) Influence of $\mathrm{CO}_{2}$ dissolution into anion exchange membrane on fuel cell performance. Electrochim Acta
88:552-558. https://doi.org/10.1016/j.electacta.2012.10. 105

[44] Krewer U, Weinzierl C, Ziv N, Dekel DR (2018) Impact of carbonation processes in anion exchange membrane fuel cells. Electrochim Acta 263:433-446. https://doi.org/10. 1016/j.electacta.2017.12.093

[45] Hickner MA, Herring AM, Coughlin EB (2013) Anion exchange membranes: current status and moving forward. J Polym Sci Part B: Polym Phys 51:1727-1735. https://doi. org/10.1002/polb.23395

[46] Couture G, Alaaeddine A, Boschet F, Ameduri B (2011) Polymeric materials as anion-exchange membranes for alkaline fuel cells. Prog Polym Sci 36:1521-1557. https:// doi.org/10.1016/j.progpolymsci.2011.04.004

[47] Ponce-González J, Whelligan DK, Wang L et al (2016) High performance aliphatic-heterocyclic benzyl-quaternary ammonium radiation-grafted anion-exchange membranes. Energy Environ Sci 9:3724-3735. https://doi.org/10.1039/ C6EE01958G

[48] Dai P, Mo Z-H, Xu R-W et al (2016) Development of a cross-linked quaternized poly(styrene-b-isobutylene-bstyrene)/graphene oxide composite anion exchange membrane for direct alkaline methanol fuel cell application. RSC Adv 6:52122-52130. https://doi.org/10.1039/ C6RA08037E

[49] Wang J, He G, Wu X et al (2014) Crosslinked poly (ether ether ketone) hydroxide exchange membranes with improved conductivity. J Membr Sci 459:86-95. https://doi. org/10.1016/j.memsci.2014.01.068

[50] Lin X, Liang X, Poynton SD et al (2013) Novel alkaline anion exchange membranes containing pendant benzimidazolium groups for alkaline fuel cells. J Membr Sci 443:193-200. https://doi.org/10.1016/j.memsci.2013.04. 059

[51] Wang J, Gu S, Kaspar RB et al (2013) Stabilizing the imidazolium cation in hydroxide-exchange membranes for fuel cells. Chemsuschem 6:2079-2082. https://doi.org/10. 1002/cssc. 201300285

[52] Guo D, Lai AN, Lin CX et al (2016) Imidazolium-functionalized poly(arylene ether sulfone) anion-exchange membranes densely grafted with flexible side chains for fuel cells. ACS Appl Mater Interfaces 8:25279-25288. https://doi.org/10.1021/acsami.6b07711

[53] Li Z, Zhang Y, Cao T et al (2017) Highly conductive alkaline anion exchange membrane containing imidazolium-functionalized octaphenyl polyhedral oligomeric silsesquioxane filler. J Membr Sci 541:474-482. https://doi. org/10.1016/j.memsci.2017.07.037

[54] Zhang Q, Li S, Zhang S (2010) A novel guanidinium grafted poly(aryl ether sulfone) for high-performance 
hydroxide exchange membranes. Chem Commun 46:7495-7497. https://doi.org/10.1039/c0cc01834a

[55] Liu L, Li Q, Dai J et al (2014) A facile strategy for the synthesis of guanidinium-functionalized polymer as alkaline anion exchange membrane with improved alkaline stability. J Membr Sci 453:52-60. https://doi.org/10.1016/j. memsci.2013.10.054

[56] Li Y, Xu T, Gong M (2006) Fundamental studies of a new series of anion exchange membranes: membranes prepared from bromomethylated poly(2,6-dimethyl-1,4-phenylene oxide) (BPPO) and pyridine. J Membr Sci 279:200-208. https://doi.org/10.1016/j.memsci.2005.12.006

[57] Sata T, Yamane Y, Matsusaki K (1998) Preparation and properties of anion exchange membranes having pyridinium or pyridinium derivatives as anion exchange groups. J Polym Sci Part A Polym Chem 36:49-58. https:// doi.org/10.1002/(SICI)1099-0518(19980115)36:1\%3C49:: AID-POLA8\%3E3.0.CO;2-X

[58] Gu S, Cai R, Yan Y (2011) Self-crosslinking for dimensionally stable and solvent-resistant quaternary phosphonium based hydroxide exchange membranes. Chem Commun 47:2856-2858. https://doi.org/10.1039/ c0cc04335d

[59] Noonan KJT, Hugar KM, Kostalik HA et al (2012) Phosphonium-functionalized polyethylene: a new class of basestable alkaline anion exchange membranes. J Am Chem Soc 134:18161-18164. https://doi.org/10.1021/ja307466s

[60] Zhang B, Gu S, Wang J et al (2012) Tertiary sulfonium as a cationic functional group for hydroxide exchange membranes. RSC Adv 2:12683-12685. https://doi.org/10.1039/ c2ra21402d

[61] Hossain MA, Jang H, Sutradhar SC et al (2016) Novel hydroxide conducting sulfonium-based anion exchange membrane for alkaline fuel cell applications. Int J Hydrog Energy 41:10458-10465. https://doi.org/10.1016/j.ijhy dene.2016.01.051

[62] Zha Y, Disabb-Miller ML, Johnson ZD et al (2012) Metalcation-based anion exchange membranes. J Am Chem Soc 134:4493-4496. https://doi.org/10.1021/ja211365r

[63] Kwasny MT, Tew GN (2017) Expanding metal cation options in polymeric anion exchange membranes. J Mater Chem A 5:1400-1405. https://doi.org/10.1039/ C6TA07990C

[64] Pan J, Chen C, Zhuang L, Lu J (2012) Designing advanced alkaline polymer electrolytes for fuel cell applications. Acc Chem Res 45:473-481. https://doi.org/10.1021/ar200201x

[65] Chempath S, Einsla BR, Pratt LR et al (2008) Mechanism of tetraalkylammonium headgroup degradation in alkaline fuel cell membranes. J Phys Chem C 112:3179-3182. https://doi.org/10.1021/jp7115577
[66] Lin B, Qiu L, Lu J, Yan F (2010) Cross-linked alkaline ionic liquid-based polymer electrolytes for alkaline fuel cell applications. Chem Mater 22:6718-6725. https://oi.org/ $10.1021 / \mathrm{cm} 102957 \mathrm{~g}$

[67] Hugar KM, Kostalik HA, Coates W (2015) Imidazolium cations with exceptional alkaline stability: a systematic study of structure-stability relationships. J Am Chem Soc 137:8730-8737. https://doi.org/10.1021/jacs.5b02879

[68] Dong H, Gu F, Li M et al (2014) Improving the alkaline stability of imidazolium cations by substitution. ChemPhysChem 15:3006-3014. https://doi.org/10.1002/cphc. 201402262

[69] Price SC, Williams KS, Beyer FL (2014) Relationships between structure and alkaline stability of imidazolium cations for fuel cell membrane applications. ACS Macro Lett 3:160-165. https://doi.org/10.1021/mz4005452

[70] Thomas OD, Soo KJWY, Peckham TJ et al (2012) A stable hydroxide-conducting polymer. J Am Chem Soc 134:10753-10756. https://doi.org/10.1021/ja303067t

[71] Sun Z, Lin B, Yan F (2017) Anion-exchange membranes for alkaline fuel-cell applications: the effects of cations. Chemsuschem. https://doi.org/10.1002/cssc.201701600

[72] Heitner-Wirguin C (1996) Recent advances in perfluorinated ionomer membranes: structure, properties and applications. J Membr Sci 120:1-33

[73] Tillet G, Boutevin B, Ameduri B (2011) Chemical reactions of polymer crosslinking and post-crosslinking at room and medium temperature. Prog Polym Sci 36:191-217. https:// doi.org/10.1016/j.progpolymsci.2010.08.003

[74] Arges CG, Ramani V (2013) Two-dimensional NMR spectroscopy reveals cation-triggered backbone degradation in polysulfone-based anion exchange membranes. Proc Natl Acad Sci 110:2490-2495. https://doi.org/10.1073/ pnas. 1217215110

[75] Nuñez SA, Hickner MA (2013) Quantitative ${ }^{1} \mathrm{H}$ NMR analysis of chemical stabilities in anion-exchange membranes. ACS Macro Lett 2:49-52. https://doi.org/10.1021/ mz300486h

[76] Sata T, Tsujimoto M, Yamaguchi T, Matsusaki K (1996) Change of anion exchange membranes in an aqueous sodium hydroxide solution at high temperature. J Membr Sci 112:161-170. https://doi.org/10.1016/03767388(95)00292-8

[77] Ameduri B (2009) From vinylidene fluoride (VDF) to the applications of VDF-containing copolymers: recent developments and future trends. Chem Rev 109:6632-6686. https://doi.org/10.1021/cr800187m\&gt

[78] Miyanishi S, Yamaguchi T (2016) Ether cleavage-triggered degradation of benzyl alkylammonium cations for polyethersulfone anion exchange membranes. Phys Chem 
Chem Phys 18:12009-12023. https://doi.org/10.1039/ C6CP00579A

[79] Han J, Peng H, Pan J et al (2013) Highly stable alkaline polymer electrolyte based on a poly(ether ether ketone) backbone. ACS Appl Mater Interfaces 5:13405-13411. https://doi.org/10.1021/am4043257

[80] Fujimoto C, Kim DS, Hibbs M et al (2012) Backbone stability of quaternized polyaromatics for alkaline membrane fuel cells. J Membr Sci 423-424:438-449. https:// doi.org/10.1016/j.memsci.2012.08.045

[81] Ponce-González J, Ouachan I, Varcoe JR, Whelligan DK (2018) Radiation-induced grafting of a butyl-spacer styrenic monomer onto ETFE: the synthesis of the most alkali stable radiation-grafted anion-exchange membrane to date. J Mater Chem A. https://doi.org/10.1039/C7TA10222D

[82] Zhu L, Pan J, Wang Y et al (2016) Multication side chain anion exchange membranes. Macromolecules 49:815-824. https://doi.org/10.1021/acs.macromol.5b02671

[83] Han J, Liu Q, Li X et al (2015) An effective approach for alleviating cation-induced backbone degradation in aromatic ether-based alkaline polymer electrolytes. ACS Appl Mater Interfaces 7:2809-2816. https://doi.org/10.1021/ am508009z

[84] Ran J, Wu L, Wei B et al (2014) Simultaneous enhancements of conductivity and stability for anion exchange membranes (AEMs) through precise structure design. Sci Rep 4:1-5. https://doi.org/10.1038/srep06486

[85] He Y, Pan J, Wu L et al (2015) A novel methodology to synthesize highly conductive anion exchange membranes. Sci Rep 5:1-7. https://doi.org/10.1038/srep13417

[86] Weiber EA, Meis D, Jannasch P (2015) Anion conducting multiblock poly(arylene ether sulfone)s containing hydrophilic segments densely functionalized with quaternary ammonium groups. Polym Chem 6:1986-1996. https://doi. org/10.1039/C4PY01588F

[87] Ren X, Price SC, Jackson AC et al (2014) Highly conductive anion exchange membrane for high power density fuel-cell performance. ACS Appl Mater Interfaces 6:13330-13333. https://doi.org/10.1021/am503870g

[88] Chen D, Hickner MA (2013) Ion clustering in quaternary ammonium functionalized benzylmethyl containing poly(arylene ether ketone)s. Macromolecules 46:9270-9278. https://doi.org/10.1021/ma401620m

[89] Pan J, Chen C, Li Y et al (2014) Constructing ionic highway in alkaline polymer electrolytes. Energy Environ Sci 7:354-360. https://doi.org/10.1039/C3EE43275K

[90] Manning GS (1969) Limiting laws and counterion condensation in polyelectrolyte solutions. III. An analysis based on the mayer ionic solution theory. J Chem Phys 51:3249-3252. https://doi.org/10.1063/1.1672502
[91] Kamcev J, Paul DR, Freeman BD (2015) Ion activity coefficients in ion exchange polymers: applicability of Manning's counterion condensation theory. Macromolecules 48:8011-8024. https://doi.org/10.1021/acs.mac romol.5b01654

[92] Muthukumar M (2004) Theory of counter-ion condensation on flexible polyelectrolytes: adsorption mechanism. J Chem Phys 120:9343-9350. https://doi.org/10.1063/1.1701839

[93] Rivas BL, Moreno-Villoslada I (1998) Binding of $\mathrm{Cd}^{2+-}$ and $\mathrm{Na}^{+}$ions by poly(sodium 4-styrenesulfonate) analyzed by ultrafiltration and its relation with the counterion condensation theory. J Phys Chem B 102:6994-6999. https://doi.org/10.1021/jp980941m

[94] Beers KM, Hallinan DT, Wang X et al (2011) Counterion condensation in Nafion. Macromolecules 44:8866-8870. https://doi.org/10.1021/ma2015084

[95] Qaisrani NA, Ma Y, Ma L et al (2018) Facile and green fabrication of polybenzoxazine-based composite anion-exchange membranes with a self-cross-linked structure. Ionics (Kiel). https://doi.org/10.1007/s11581-017-2433-y

[96] Pandey AK, Childs RF, West M et al (2001) Formation of pore-filled ion-exchange membranes within situ crosslinking: poly(vinylbenzyl ammonium salt)-filled membranes. J Polym Sci Part A Polym Chem 39:807-820. https://doi. org/10.1002/1099-0518(20010315)39:6\%3C807::AIDPOLA1054\%3E3.0.CO;2-2.

[97] Kuzume A, Miki Y, Ito M (2013) Characterisation of PAMPS-PSS pore-filling membrane for direct methanol fuel cell. J Membr Sci 446:92-98. https://doi.org/10.1016/j. memsci.2013.06.032

[98] Lee M-S, Kim T, Park S-H et al (2012) A highly durable cross-linked hydroxide ion conducting pore-filling membrane. J Mater Chem 22:13928-13931. https://doi.org/10. 1039/c2jm32628k

[99] Maurya S, Shin S, Kim M et al (2013) Stability of composite anion exchange membranes with various functional groups and their performance for energy conversion. J Membr Sci 443:28-35. https://doi.org/10.1016/j.memsci. 2013.04.035

[100] Yamaguchi T, Miyata F, Nakao SI (2003) Pore-filling type polymer electrolyte membranes for a direct methanol fuel cell. J Membr Sci 214:283-292. https://doi.org/10.1016/ S0376-7388(02)00579-3

[101] Jiang S, Ladewig BP (2017) High ion-exchange capacity semihomogeneous cation exchange membranes prepared via a novel polymerization and sulfonation approach in porous polypropylene. ACS Appl Mater Interfaces 9:38612-38620. https://doi.org/10.1021/acsami.7b13076

[102] Kickelbick G (2003) Concepts for the incorporation of inorganic building blocks into organic polymers on a 
nanoscale. Prog Polym Sci 28:83-114. https://doi.org/10. 1016/S0079-6700(02)00019-9

[103] Wu Y, Wu C, Xu T, Fu Y (2009) Novel anion-exchange organic-inorganic hybrid membranes prepared through solgel reaction of multi-alkoxy precursors. J Membr Sci 329:236-245. https://doi.org/10.1016/j.memsci.2008.12. 056

[104] Bakangura E, Wu L, Ge L et al (2016) Progress in polymer science mixed matrix proton exchange membranes for fuel cells: state of the art and perspectives. Prog Polym Sci 57:103-152. https://doi.org/10.1016/j.progpolymsci.2015. 11.004

[105] Laberty-Robert C, Vallé K, Pereira F, Sanchez C (2011) Design and properties of functional hybrid organic-inorganic membranes for fuel cells. Chem Soc Rev 40:961-1005. https://doi.org/10.1039/c0cs00144a

[106] Giorno L, Drioli E, Strathmann H (2016) Ion-exchange membrane characterization. In: Drioli E, Giorno L (eds) Encyclopedia of Membranes. Springer, Berlin, Heidelberg

[107] Berezina NP, Kononenko NA, Dyomina OA, Gnusin NP (2008) Characterization of ion-exchange membrane materials: properties vs structure. Adv Colloid Interface Sci 139:3-28. https://doi.org/10.1016/j.cis.2008.01.002

[108] Sata T (2007) Ion exchange membranes: preparation, characterization, modification and application. Royal Society of Chemistry, Cambridge

[109] Karas F, Hnát J, Paidar M et al (2014) Determination of the ion-exchange capacity of anion-selective membranes. Int $\mathrm{J}$ Hydrog Energy 39:5054-5062. https://doi.org/10.1016/j. ijhydene.2014.01.074

[110] Hong T-K, Kim M-H, Czae M-Z (2010) Determination of chlorinity of water without the use of chromate indicator. Int J Anal Chem 2010:1-7. https://doi.org/10.1155/2010/ 602939

[111] Leng G (2002) Chromium and its compounds [MAK Value Documentation, 1992]. In: The MAK-Collection for Occupational Health and Safety. Wiley-VCH Verlag GmbH \& Co. $\mathrm{KGaA}$

[112] Faraj M, Boccia M, Miller H et al (2012) New LDPE based anion-exchange membranes for alkaline solid polymeric electrolyte water electrolysis. Int $\mathrm{J}$ Hydrog Energy 37:14992-15002. https://doi.org/10.1016/j.ijhydene.2012. 08.012

[113] Deavin OI, Murphy S, Ong AL et al (2012) Anion-exchange membranes for alkaline polymer electrolyte fuel cells: comparison of pendent benzyltrimethylammoniumand benzylmethylimidazolium-head-groups. Energy Environ Sci 5:8584-8597. https://doi.org/10.1039/c2ee22466f

[114] Khan MI, Luque R, Akhtar S et al (2016) Design of anion exchange membranes and electrodialysis studies for water desalination. Mater (Basel) 9:1-14. https://doi.org/10.3390/ ma9050365

[115] Tanaka Y (2007) Ion exchange membranes: fundamentals and applications. Elsevier, Amsterdam

[116] Strathmann H (2004) Ion-exchange membrane separation processes. Elsevier, Amsterdam

[117] Luo X, Wright A, Weissbach T, Holdcroft S (2018) Water permeation through anion exchange membranes. J Power Sources 375:442-451. https://doi.org/10.1016/j.jpowsour. 2017.05.030

[118] Park J-S, Choi J-H, Woo J-J, Moon S-H (2006) An electrical impedance spectroscopic (EIS) study on transport characteristics of ion-exchange membrane systems. J Colloid Interface Sci 300:655-662. https://doi.org/10.1016/j. jcis.2006.04.040

[119] Müller F, Ferreira CA, Azambuja DS et al (2014) Measuring the proton conductivity of ion-exchange membranes using electrochemical impedance spectroscopy and through-plane cell. J Phys Chem B 118:1102-1112. https:// doi.org/10.1021/jp409675z

[120] Wright AG, Fan J, Britton B et al (2016) Hexamethyl-pterphenyl poly(benzimidazolium): a universal hydroxideconducting polymer for energy conversion devices. Energy Environ Sci 9:2130-2142. https://doi.org/10.1039/ C6EE00656F

[121] Dekel DR, Amar M, Willdorf S et al (2017) Effect of water on the stability of quaternary ammonium groups for anion exchange membrane fuel cell applications. Chem Mater 29:4425-4431. https://doi.org/10.1021/acs.chemmater. $7 \mathrm{~b} 00958$

[122] Fang J, Yang Y, Lu X et al (2012) Cross-linked, ETFEderived and radiation grafted membranes for anion exchange membrane fuel cell applications. Int $\mathrm{J}$ Hydrog Energy 37:594-602. https://doi.org/10.1016/j.ijhydene. 2011.09.112

[123] Stokes KK, Orlicki JA, Beyer FL (2010) RAFT polymerization and thermal behavior of trimethylphosphonium polystyrenes for anion exchange membranes. Polym Chem 2:80-82. https://doi.org/10.1039/C0PY00293C

[124] Mabrouk W, Ogier L, Vidal S et al (2014) Ion exchange membranes based upon crosslinked sulfonated polyethersulfone for electrochemical applications. J Membr Sci 452:263-270. https://doi.org/10.1016/j.memsci.2013.10. 006

[125] Narducci R, Chailan J-F, Fahs A et al (2016) Mechanical properties of anion exchange membranes by combination of tensile stress-strain tests and dynamic mechanical analysis. J Polym Sci Part B Polym Phys 54:1180-1187. https://doi. org/10.1002/polb.24025 